Review article

\title{
Management of postoperative pain
}

\author{
Denisa Macková ${ }^{1,2}$ * , Andrea Pokorná ${ }^{3}$ \\ ${ }^{1}$ King Abdulaziz Medical City - National Guard Health Affairs, Riyadh, Kingdom of Saudi Arabia \\ ${ }^{2}$ University of Ostrava, Faculty of Medicine, Department of Nursing and Midwifery, Ostrava, Czech Republic \\ ${ }^{3}$ Masaryk University, Faculty of Medicine, Department of Nursing and Midwifery, Brno, Czech Republic
}

\begin{abstract}
Aim: To evaluate available scientific findings on the management of postoperative pain. Literature review is the basis for the research, examining the nurses' knowledge and experience in post-operative pain management (in both the Czech Republic and the Kingdom of Saudi Arabia).

Methods: Literature review - selected keywords (using Boolean operators) were searched in electronic databases (MEDLINE, EBSCO, CINAHL, ACADEMIC SEARCH ULTIMATE, SCIENCE DIRECT).

Results: A total of 469 sources were found. 25 sources meeting the criteria were subjected to critical analysis. A total of 7 studies were selected for the final analysis.

Conclusions: International guidelines are available for the treatment of postoperative pain, but according to the sources analysed, the guidelines are not applied in clinical practice. The results of the literature review have shown that there are deficiencies, especially in the knowledge of general nurses and the management of postoperative pain. It was also shown that the standardised procedures and tools for assessing pain in the patients' early postoperative period are not used. Specialised findings recommend placing more emphasis on the training and education of general nurses in the management of postoperative pain, and on evaluating the pain of the patient in the early postoperative period.
\end{abstract}

Keywords: In-patient; Management; Nurse; Pharmacology; Postoperative pain

\section{Introduction}

The management of postoperative pain is an integral part of health care (nursing, medical) for a patient in the early postoperative period, regardless of the type of surgical department (postoperative department, standard department, day surgery, ICU or ARO).

Treatment of postoperative pain requires adequate nursing expertise to manage pain in the patient. According to the International Association for the Study of Pain (IASP), pain is defined as "an unpleasant sensory and emotional experience that is associated with actual or potential tissue damage" (IASP, 2017). One of the frequently mentioned types of acute pain is postoperative pain that accompanies the patient in connection with surgery. Postoperative pain is accompanied by the fear experienced by patients who are about to undergo surgery (Gabrhelík and Pieran, 2012). It is precisely for this reason that it is necessary to bear in mind that when patients are plagued by the fear of postoperative pain, which leads to an unpleasant experience, it is important to emphasize adequate education of health professionals and their ability to provide an appropriate form of support in managing postoperative pain. Appropriate pain scales must be used to determine the pain intensity in patients appropriately. Based on their abili- ties and knowledge, general nurses must be able to determine the right range for assessing pain in different age categories of patients, patients who are unable to communicate verbally, etc. In addition, it is important that nurses know the individual components of effective pain management ( $\mathrm{Ng}$ and Cashman, 2018). General nurses must emphasise a range of interventions during post-operative pain treatment: pain assessment, analgesics, interventions, etc. In order for post-operative pain management to be effective in patients, pain must be properly evaluated. Each patient must be evaluated individually, even when the surgery is the same, as a patient's response to pain is individual. When evaluating pain, the general nurse must pay attention to whether the pain is at rest or in movement, whether the pain is at the site of surgery or whether the location of the painful manifestation is different. The general nurse must assess the patient's pain at regular intervals during the postoperative period. If the patient complains of pain, it is the nurse's responsibility to administer the prescribed analgesics to assess the effect of the administered medications or, on the contrary, to assess the adverse effects that the medication may cause to the patient. Another important role of the general nurse in the management of postoperative pain is documenting the above mentioned interventions carried out by the nurse (Yüceer, 2011).

\footnotetext{
* Author for correspondence: Denisa Macková, University of Ostrava, Faculty of Medicine, Department of Nursing and Midwifery, Syllabova 19, 70030 Ostrava-Vítkovice, Czech Republic; e-mail: denisa.mackova@seznam.cz; mackovade@ngha.med.sa http://doi.org/10.32725/kont.2020.018
}

Submitted: 2019-12-05 • Accepted: 2020-04-22 • Prepublished online: 2020-04-30 
Treatment of postoperative pain and knowledge of treatment are very important for patients during the postoperative period. It is important to insist on the adequate training of medical and nursing staff in order to provide adequate treatment for postoperative pain to all patients. There are a number of treatments for postoperative pain. The basic division is non-pharmacological and pharmacological procedures (Gabrhelík and Pieran, 2012). A variety of procedures and methods are used to treat postoperative pain. These methods include psychological methods such as hypnosis, and physical methods, including cold, heat, massages, acupuncture, rehabilitation, position changes, breathing exercises, music therapy, etc. (Málek et al., 2017). In some cultures, prayer and the fulfillment of spiritual needs help to relieve pain (Yaban, 2019). Non-pharmacological treatment of postoperative pain is followed by pharmacological treatment. There are a number of non-opioid and opioid analgesics that are administered to patients to control postoperative pain. Pharmacological treatment clearly dominates non-pharmacological procedures (Gabrhelík and Pieran, 2012). An important and useful model for understanding the experience of acute patient pain consists of four processes: transduction, transmission, perception and modulation. Understanding the underlying model that provides a cognitive map of pain perception is also likely to be an effective treatment for postoperative pain (Chapman and Lalkhen, 2016).

\section{Objectives}

The aim of the literature review was to identify studies focused on the management of postoperative pain in patients. The aim was to investigate the postoperative pain management procedures in various workplaces and to analyse studies already published. We were interested in published sources about trends and procedures in the management of postoperative pain (both in the Czech Republic and abroad). The aim was to explore the main intention in pain management and specifically individual interventions carried out by a nurse to effectively influence pain in patients.

The results of the literary review will serve as a starting point for the research, which analyses the knowledge and experience of nurses in the management of postoperative pain in the Czech Republic and the Kingdom of Saudi Arabia.

\section{Materials and methods}

The basic criterion for the inclusion of studies was that they had to be original research work of various methodologies (prospective and retrospective studies, quantitative descriptive cross-sectional studies, qualitative studies, clinical studies - quasi-experiment, etc.) with a focus on post-operative pain management and post-operative pain. Of course, individual studies had to meet the requirements of IMRaD (Introduction, Methods, Results and Discussion). The study only included professional resources that focused on pain management in hospitalised adult patients. Pain management in the pediatric population was eliminated in the literature review (using the Boolean NOT operator and the keywords "children, baby"). The literary review takes the form of a rapid literature review.

The search for source information was limited to the available sources between 2014 and 2019. The available sources were searched through the databases MEDLINE, EBSCO, CINAHL, ACADEMIC SEARCH ULTIMATE, SCIENCE DIRECT. Only freely available full texts were analysed in the research. Resources in English or Czech language were analysed and only full-text versions of professional resources were used.
Within the search strategy the following keywords were chosen: postoperative pain, management, nurse, in-patient, pharmacological. We also used a character ("*”) that was used to extend the keyword base with additional options and was only used in conjunction with the keyword "nurs*". In addition, we used Boolean operators, including (AND, NOT, OR), to search for suitable sources in databases. The use of selected operators "AND" enabled the finding of a connection between postoperative pain and pain treatment. The use of the "(*)" character helped to extend the word "nurs*" to nurse, nursing, nurses, etc. The introduction of the negative "NOT" operator excluded sources in databases concerning pediatric patients and treatment of postoperative pain in NOT children, baby. The keyword "pharmacological" has been added to the original search keywords above. While searching without the keyword "pharmacological", a large number of publications were generated. The total came to 4,529 , which included non-pharmacological methods and decision-making processes that were not related to pain management in nursing care. The total number of searched publications in these databases was 1,233, but after the restriction to only free (full-text) sources, 469 sources were analysed.

\section{Description of search and analysis strategy}

25 relevant sources were used for a detailed final evaluation of the available professional resources. The procedure for selecting sources within the literature search is shown in Fig. 1.

\section{Description of the search process}

A total of 318 sources were searched in the MEDLINE (PubMed) database, but after selecting only those for 2014-19 that were freely available full-text sources, 180 sources were discarded, leaving 138 sources for analysis. In the course of the first-stage analysis, 132 sources were discarded due to duplicity of sources or due to failure to meet the criteria for finding suitable publications. $N=6$ results from the database were used for the second-stage analysis.

A total of 482 sources were searched in the SCIENCE DIRECT database, but after selecting only those for 201419 that were freely available full-text sources, 340 sources were discarded, leaving 142 sources for analysis. During the first-level analysis, 133 sources were eliminated - again due to duplicity of articles, failure to meet the criteria for searching suitable publications, or due to the occurrence of articles that served as educational material and abstracts for a conference. $N=9$ sources from the database were used for the second-stage analysis.

A total of 254 sources were searched in the ACADEMIC SEARCH ULTIMATE database, but after selecting only those for 2014-19 that were freely available full-text sources, 122 sources were discarded, leaving 132 sources for analysis. During the first level analysis, 126 sources were eliminated again for the same reasons - namely duplicity of articles and failure to meet the specified criteria. Publications published in a language other than English (Polish, Greek, Spanish and Arabic) were also excluded. $N=6$ sources from the database were used for the second-stage analysis.

A total of 179 sources were searched in the CINAHL database, but after selecting only those for 2014-19 that were freely available full-text sources, 122 sources were discarded, leaving 57 sources for analysis. During the first-stage analysis, 53 sources were excluded due to failure to meet the criteria for searching suitable publications. $N=4$ sources from this database were used for the second stage analysis. 


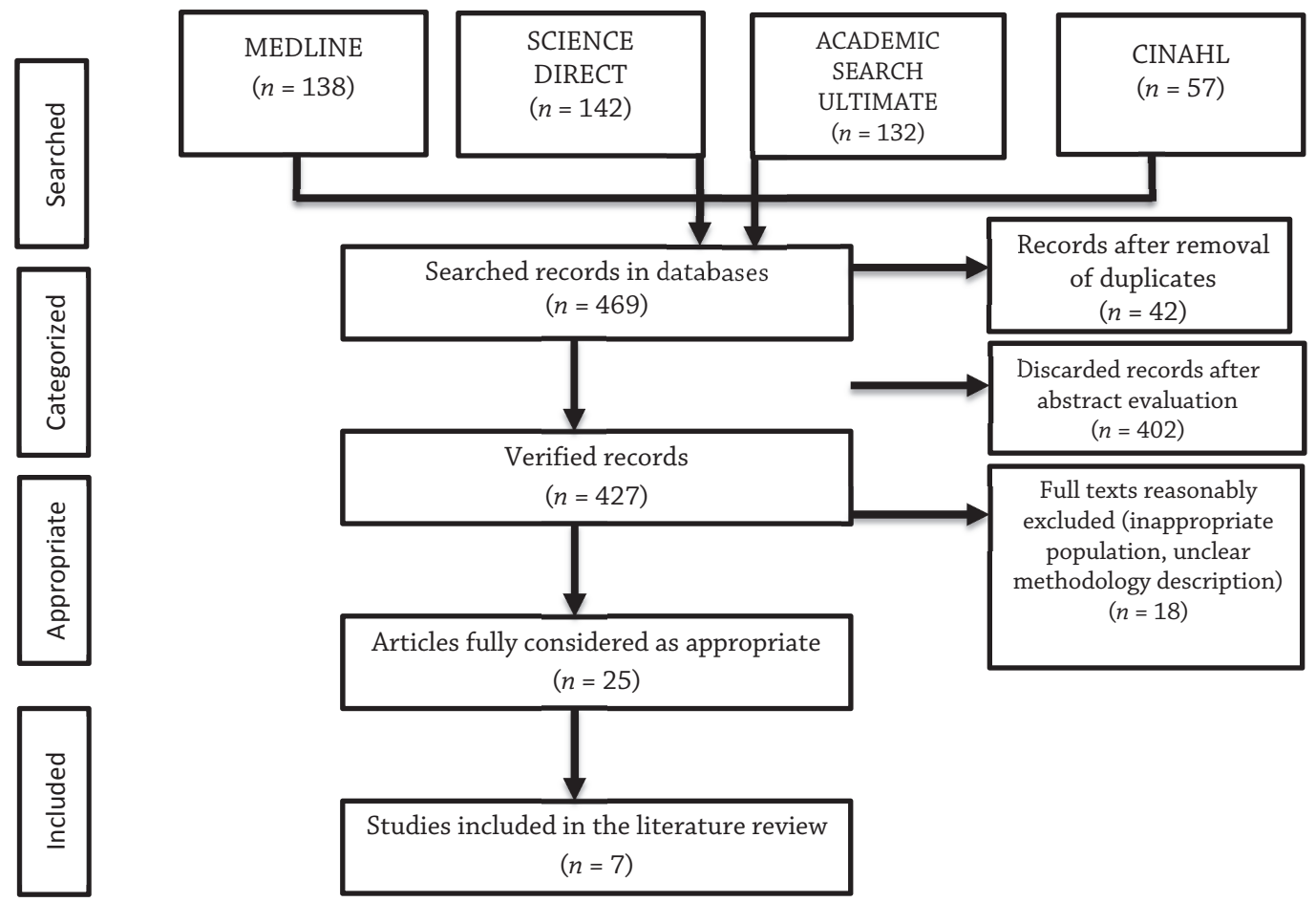

Fig. 1. Flow diagram - PRISMA

\section{Results and discussion}

All excluded and selected contributions are clearly presented in Table 1. For the second-stage analysis from all databases, 25 contributions were submitted.

An overview of the thematic focus of the individually selected studies can be seen in Table 1 . This shows which issues were most frequently studied and which method of study was chosen. Two categories were created from the studies found by the authors. In the first category, the titles and methodology of the obtained studies were used to identify studies which focused on the management of postoperative pain in clinical practice. The second category contained studies dealing with postoperative pain in a broader context, for example from the perspective of professional care takers (healthcare providers). The most frequently studied topic was pain management, where 7 studies were analysed (Table 2). One study also included a study focusing on the management of postoperative pain in a tertiary hospital in Tanzania (Masigati and Chilonga, 2014), which was elaborated by a descriptive prospective hospital-based study. Another study was conducted as a prospective cross-sectional study, which deals with postoperative pain issues among surgically treated patients in Ethiopian hospitals (Woldehaimanot et al., 2014).

In addition, a study evaluating the Chinese version of the revised American Pain Society questionnaire was found regarding pain management in Chinese patients after orthopedic interventions (Fang et al., 2017) - in which the authors report using the psychometric evaluation method. In addition, one descriptive point prevalence study, literature research, educational material and a clinical study - quasi-experiment were found.
Another frequently studied topic was postoperative pain in a broader context. Three studies were analyzed in this category. One was a study of post-operative pain evaluation from the perspective of nurses (Xavier et al., 2018), which was elaborated by a qualitative, descriptive and exploratory study. Another topic was elaborated in a prospective longitudinal study, in which the authors discussed the quality of treatment for postoperative pain in Ethiopia (Eshete et al., 2019). Another study was a prospective multicentre study aimed at improving postoperative pain, and identifying options and problems (Pogatzki-Zahn et al., 2015). The last study was post-operative pain control, where Borys et al. (2018) investigated postoperative pain control through a prospective observational study.

In the literature search, seven expert sources were thoroughly analyzed, the results of which show that the authors of the individual studies reached similar conclusions. The first study was published in May 2019, entitled "Quality of Postoperative Pain Management in Ethiopia - a Longitudinal Prospective Study", with a total of 356 patients, by Eshete et al. (2019). The aim was to evaluate the quality of treatment of postoperative pain in patients from Ethiopia who were to undergo surgery from general surgery, gynecology and orthopedics. Through an international pain questionnaire, the authors quantified the prevalence from moderate to severe postoperative pain. The questionnaire assessed the severity of pain, its physical and emotional interference, and patient satisfaction with pain management at four intervals $(6,12$, 24 and 48 hours). The study was conducted in three hospitals in Ethiopia. Data were obtained by general nurses who interviewed patients. Patients who could not read, write or were serious about their health were excluded from the study. The nurses that collected the data did not participate in postoperative pain management in specific patients to avoid biasing 
Table 1. Analysed studies (full text) meeting the basic criteria $(n=25)$

\begin{tabular}{|c|c|c|}
\hline Focus of the study & Frequency of sources found & Methodology \\
\hline $\begin{array}{l}\text { Postoperative pain control } \\
\text { Borys et al. (2018) }\end{array}$ & 1 & Prospective study by observation $\mathbf{1}$ \\
\hline $\begin{array}{l}\text { Evaluation of postoperative pain } \\
\text { de Castro et al. (2018); Erden et al. (2017) }\end{array}$ & 2 & $\begin{array}{l}\text { Quantitative prospective and descriptive cross-sectional } \\
\text { study } \mathbf{1} \\
\text { Descriptive and retrospective study } \mathbf{1}\end{array}$ \\
\hline $\begin{array}{l}\text { Management/Treatment of pain } \\
\text { Fang et al. (2017); Masigati and Chilonga (2014); } \\
\text { Ng and Cashman (2018); Schreiber et al. (2014); } \\
\text { Woldehaimanot et al. (2014); Yassin et al. (2015); } \\
\text { Zoëga, et al. (2014) }\end{array}$ & 7 & $\begin{array}{l}\text { Literature review } \mathbf{1} \\
\text { Prospective cross-sectional study } \mathbf{1} \\
\text { Descriptive prospective study } \mathbf{1} \\
\text { Psychometric evaluation } \mathbf{1} \\
\text { Clinical study - quasi-experiment } \mathbf{1} \\
\text { Descriptive study of point prevalence } \mathbf{1} \\
\text { Educational material - publication } \mathbf{1}\end{array}$ \\
\hline $\begin{array}{l}\text { Postoperative pain } \\
\text { Eshete et al. (2019); Pogatzki-Zahn et al. (2015); } \\
\text { Xavier et al. (2018) }\end{array}$ & 3 & $\begin{array}{l}\text { Longitudinal / long-term prospective study } \mathbf{1} \\
\text { Prospective multicentre study } \mathbf{1} \\
\text { Descriptive qualitative and exploratory study } \mathbf{1}\end{array}$ \\
\hline $\begin{array}{l}\text { Management of patients before surgical or interventional } \\
\text { pain interventions } \\
\text { Jonan et al. (2018) }\end{array}$ & 1 & Clinical study $\mathbf{1}$ \\
\hline $\begin{array}{l}\text { Intensity of pain } \\
\text { Veal et al. (2017) }\end{array}$ & 1 & Prospective observational study $\mathbf{1}$ \\
\hline $\begin{array}{l}\text { Postoperative change of cognitive functions } \\
\text { Di Santo (2019) }\end{array}$ & 1 & Literature review $\mathbf{1}$ \\
\hline $\begin{array}{l}\text { Opioid analgesia } \\
\text { Azam et al. (2017); Jungquist et al. (2014); } \\
\text { Minkowitz et al. (2014) }\end{array}$ & 3 & $\begin{array}{l}\text { Basic clinical practice studies } \mathbf{1} \\
\text { Systematic approach } \mathbf{1} \\
\text { Retrospective cohort study } \mathbf{1}\end{array}$ \\
\hline $\begin{array}{l}\text { Patient Controlled Analgesia (PCA) } \\
\text { Madsen et al. (2018) }\end{array}$ & 1 & "Before" and "after" intervention studies $1 \mathbf{1}$ \\
\hline $\begin{array}{l}\text { Bio-psycho-social approach to pain management } \\
\text { Riswold et al. (2018) }\end{array}$ & 1 & Validated survey $\mathbf{1}$ \\
\hline $\begin{array}{l}\text { Nursing education } \\
\text { Drake and de C Williams (2017) }\end{array}$ & 1 & Systematic review $\mathbf{1}$ \\
\hline $\begin{array}{l}\text { Patient's experience with pain } \\
\text { Angelini et al. (2018) }\end{array}$ & 1 & Interview $\mathbf{1}$ \\
\hline $\begin{array}{l}\text { Postoperative analgesia } \\
\text { Chapman and Lalkhen (2016) }\end{array}$ & 1 & Educational material - publication $\mathbf{1}$ \\
\hline $\begin{array}{l}\text { Postoperative care } \\
\text { Tyson and Creagh-Brown (2018) }\end{array}$ & & Educational material - publication $\mathbf{1}$ \\
\hline
\end{tabular}

the measurement results. The authors found that moderate and severe postoperative pain was present in the majority of patients $(88.2 \%)$, of which postoperative pain was not treated effectively in more than half (58.4\%). In this case, no gender was involved, and no gender relationship was established. In the study, women predominated (51.1\%). Patient satisfaction was not expected due to the severe pain intensity. The authors found that the prevalence of moderate and severe postoperative pain and functional interference in Ethiopian patients is high. It has been found that the treatment provided to their patients cannot be considered adequate and, in particular, does not comply with international standards and recommendations.

Woldehaimanot et al. (2014) published a prospective cross-sectional study entitled "Management of postoperative pain among surgical patients in Ethiopian hospitals". The study was conducted in 252 postoperative patients. Data was collected from February 2012 to the end of April 2012. A validated questionnaire from the American Pain Society Patient Outcome Questionnaire was used to assess pain in patients.
Patients selected for the study had to meet the inclusion criteria: age over 18 years and postoperative periods of 24 and 72 hours. The incidence of pain in patients was very high (91.4\%). In most surgical patients $(80.1 \%)$, postoperative pain was found to be inadequately treated. The authors of the study revealed that despite the high satisfaction of patients with postoperative pain treatment, most patients suffered from severe pain and the treatment was inadequate. The authors recommended further research to remove barriers that prevent sufficient and effective treatment of postoperative pain in surgical patients in Ethiopian hospitals.

Another study included in our literature review is entitled "Review of Postoperative Pain Control in Different Types of Hospitals: Multicentric Observation Study" - published by Borys et al. (2018). Research was conducted in seven hospitals in eastern Poland. 269 women and 293 men participated in the study. The aim of the study was to assess the severity of pain in patients from different types of hospitals after similar types of operations. Another aim was to determine if there are differences in pain intensity associated with the technique of 
Table 2. Results of the second stage analysis $(n=7)$

\begin{tabular}{|c|c|c|c|c|c|}
\hline Author & Title & Country & $\begin{array}{l}\text { Sample of } \\
\text { respondents }\end{array}$ & Type of study & Conclusion and recomendation \\
\hline Eshete et al. (2019) & $\begin{array}{l}\text { Quality of postoperative pain } \\
\text { management in Ethiopia: } \\
\text { A prospective longitudinal } \\
\text { study }\end{array}$ & Ethiopia & $N=356$ & $\begin{array}{l}\text { Longitudinal, } \\
\text { prospective } \\
\text { study }\end{array}$ & $\begin{array}{l}\text { Treatment of postoperative pain } \\
\text { provided to patients in Ethiopia } \\
\text { is inadequate and not in line with } \\
\text { international recommendations and } \\
\text { standards. }\end{array}$ \\
\hline Xavier et al. (2018) & $\begin{array}{l}\text { Evaluation of post-operative } \\
\text { pain under the nurse's point } \\
\text { of view }\end{array}$ & Brazil & $N=12$ & $\begin{array}{l}\text { Descriptive } \\
\text { qualitative and } \\
\text { exploratory } \\
\text { study }\end{array}$ & $\begin{array}{l}\text { According to the study, the general } \\
\text { nurses do not use any standardised } \\
\text { tools to evaluate the proper treatment } \\
\text { of pain. The authors recommend the } \\
\text { education of nurses to implement the } \\
\text { postoperative pain assessment model. }\end{array}$ \\
\hline $\begin{array}{l}\text { Pogatzki-Zahn et al. } \\
\text { (2015) }\end{array}$ & $\begin{array}{l}\text { A Prospective Multicentre } \\
\text { Study to Improve } \\
\text { Postoperative Pain: } \\
\text { Identification of Potentialities } \\
\text { and Problems }\end{array}$ & Germany & $\begin{array}{l}\text { Preoperative period } \\
N=708 \\
\text { Postoperative } \\
\text { period } N=935\end{array}$ & $\begin{array}{l}\text { Prospective } \\
\text { multicentre } \\
\text { study }\end{array}$ & $\begin{array}{l}\text { The study improved pain assessments, } \\
\text { particularly in certain specific patient } \\
\text { subgroups, highlighting the benefits } \\
\text { of a perioperative training program. }\end{array}$ \\
\hline $\begin{array}{l}\text { Woldehaimanot et al. } \\
\text { (2014) }\end{array}$ & $\begin{array}{l}\text { Post-operative pain } \\
\text { management among } \\
\text { surgically treated patients in } \\
\text { an Ethiopian hospital }\end{array}$ & Ethiopia & $N=252$ & $\begin{array}{l}\text { Prospective } \\
\text { cross-sectional } \\
\text { study }\end{array}$ & $\begin{array}{l}\text { The pain was treated inappropriately } \\
\text { and inadequately. }\end{array}$ \\
\hline $\begin{array}{l}\text { Masigati and Chilonga } \\
\text { (2014) }\end{array}$ & $\begin{array}{l}\text { Post-operative pain } \\
\text { management outcomes } \\
\text { among adults treated at a } \\
\text { tertiary hospital in Moshi, } \\
\text { Tanzania }\end{array}$ & Tanzania & $N=124$ & $\begin{array}{l}\text { Prospective } \\
\text { descriptive } \\
\text { study }\end{array}$ & $\begin{array}{l}\text { The treatment of postoperative pain } \\
\text { is a constant major challenge in their } \\
\text { healthcare facility. }\end{array}$ \\
\hline Borys et al. (2018) & $\begin{array}{l}\text { Survey of post-operative pain } \\
\text { control in different types } \\
\text { of hospitals: a multicentre } \\
\text { observational study }\end{array}$ & Poland & $\begin{array}{c}N=562 \\
(269 \text { female, } \\
293 \text { male) }\end{array}$ & $\begin{array}{l}\text { Prospective } \\
\text { observation } \\
\text { method }\end{array}$ & $\begin{array}{l}\text { The authors agreed that the } \\
\text { results of their study conflict with } \\
\text { the recommended international } \\
\text { guidelines for the treatment of } \\
\text { postoperative pain. }\end{array}$ \\
\hline Erden et al. (2019) & $\begin{array}{l}\text { A review of post-operative } \\
\text { pain assessment records of } \\
\text { nurses }\end{array}$ & Turkey & $N=956$ & $\begin{array}{l}\text { Retrospective } \\
\text { descriptive } \\
\text { study }\end{array}$ & $\begin{array}{l}\text { The results of the study showed that } \\
\text { pain assessment is not performed in } \\
\text { accordance with the pain assessment } \\
\text { guidelines. }\end{array}$ \\
\hline
\end{tabular}

anesthesia, the type of surgery, or the age and sex of the patient. A questionnaire form was used for the survey. A visual analogue scale was used to measure pain intensity at four time intervals after surgery. It was found that in the fourth measurement, $39.32 \%$ of patients rated pain as moderate and $19.75 \%$ rated pain as severe. The survey also showed that postoperative pain control after single spinal anesthesia is insufficient. Satisfactory outcomes of postoperative pain treatment were seen in vascular surgery patients with the lowest pain intensity, particularly compared to patients undergoing chest surgery. The authors agreed that the study brought new variables that greatly affect the intensity of pain, the location of pain, the type of anesthesia and also the type of surgery. The authors report that the findings of the study conflict with the recommended national guidelines and procedures for the treatment of postoperative pain.

Masigati and Chilonga (2014) published a prospective descriptive study entitled "Results of postoperative pain management in adults treated in tertiary hospitals in Moshi, Tanzania". The study included 124 patients, of whom 59 were women and 65 were men. The study investigated the treatment of postoperative pain and patient satisfaction with postoperative pain. If the treatment of postoperative pain is inadequate, patients are at risk of complications. This means their condition can worsen, which in some cases can have fatal con- sequences. Inadequate postoperative pain treatment is also costly for hospitals, as the duration of the patients' hospital stay will be longer and thus the overall cost of hospitalisation increases. The study was conducted to assess postoperative pain and patient satisfaction at Kilimanjaro Medical Centre. Postoperative pain and patient satisfaction with pain relief were evaluated using a numerical pain and satisfaction scale. Postoperative pain was evaluated at intervals of 24 hours after surgery and 48 hours after surgery. Patients' satisfaction with treatment was assessed 48 hours after surgery. The results show that the greatest percentage of patients had mild pain at rest and when moving. It was also shown that patients who received an analgesic intravenously were more satisfied with pain management than patients who received analgesics intramuscularly. The authors concluded that in their hospital, treatment of postoperative pain is still a major challenge as almost half of the patients had mild pain within the first 48 hours after surgery.

The above studies mainly focused on the treatment of postoperative pain in patients in different countries (Ethiopia, Tanzania or Poland). Based on the results of the authors of the individual studies, we can conclude that, although there are international standards for the treatment of postoperative pain, patients still experience inadequate treatment. The authors agree that the treatment of postoperative pain is a constant 
challenge and it is essential that treatment be provided in accordance with international standards.

In the following studies, the authors focused on the evaluation of postoperative pain and records on the evaluation of postoperative pain by general nurses. One study was conducted in Brazil and the other in Turkey. In both cases, the conclusions show a lack of awareness and education of nurses in the management of postoperative pain. The first study under review entitled "Evaluation of Postoperative Pain from the Nursing Point of View" was published by Xavier et al. (2018). The study included 12 general nurses and was a descriptive qualitative and exploratory study conducted in a public hospital in Brazil. The aim of the study was to identify the form of general nurses assessing and controlling acute postoperative pain in patients after surgery. The respondents were general nurses working in the postoperative - adolescent ward, and general nurses from the surgical wards. The data was collected using the method of a semi-structured interview, which consisted of two parts. The first part was aimed at identifying general nurses (gender, age, etc.), and the second part focused on information relevant to this study, which included questions about the practice of assessing postoperative pain and managing acute pain in postoperative patients. The authors concluded that the nurses who participated in the study do not use any standardised tool to assess pain in postoperative patients, and pain control is based on prescribed analgesia. In their conclusion, the authors recommended that adequate training and education on post-operative pain management should be carried out, as well as the implementation of an appropriate pain assessment tool to more effectively control post-operative pain.

Erden et al. (2017) published a study entitled "Nursing Records on Postoperative Pain Assessment". It was a retrospective descriptive study to examine nurses' records of postoperative pain assessments. Medical records of 956 patients who were admitted to hospital for surgery between January 2014 and January 2015 in a hospital in Balcali, Turkey, were examined. The data was collected using a general nurse's questionnaire and pain assessment form. All data was collected by researchers who did not work as nurses in the hospital. In the first 48 hours, postoperative records revealed that no patient had any information regarding pain assessment (intensity, location of pain, duration of pain, type of pain). The highest postoperative pain scores were recorded within the first two hours after surgery. The results of the study showed that within 48 hours after surgery, there was no record to point to more detailed evaluation and monitoring of postoperative pain. The study pointed to a problem with the evaluation of postoperative pain, because the evaluation of pain by general nurses was not in accordance with the guidelines for pain assessment and there were no records of analgotherapy. Pain should be monitored as a vital function, and pain assessment should be given high priority. The authors suggested that online courses on pain management, regular post-operative follow-up and pain assessment should be prepared. They stated that it was necessary to ensure that general nurses had sufficient education about the importance of pain assessment in the postoperative period.

Pogatzki-Zahn et al. (2015) published a study entitled "Prospective Multicentre Study to Improve Postoperative Pain - Identifying Possibilities and Problems". The study was part of the Health Alliance Pain-Free City Muenster project, which was carried out from January 2010 to December 2013. The research was conducted in six non-university hospitals in Muenster, Germany. 1,486 patients were enrolled in the study during the preoperative period, but 778 patients were exclud- ed and only 708 patients were subjected to final analysis. In the postoperative period, 1,695 patients were monitored, but again some probands were excluded and 935 patients were selected for final analysis. Each hospital was involved in data collection twice - once before and once after the implementation of internal training concepts. All stakeholders in the postoperative pain management process were involved: patients, general nurses, doctors and anesthesiologists. They were interviewed through a standardised questionnaire. At each hospital, patients were enrolled in the study the first day after planned surgery, and pain assessment and comparison were performed before and after surgery between groups from all hospitals. The exclusion criteria were those who refused to participate in the study, patients under 18 years, patients in the intensive care unit or patients with insufficient knowledge of the German language. In patients without significant preoperative pain, there was a significantly lower change in postoperative pain - both at rest and during exercise. Significant changes were identified after chest surgery, small joint surgery, and other mini-invasive surgery. An interesting result was that post-test pain was significantly lower compared to pre-test pain, but only in patients without previous chronic pain. The side effects associated with analgesics were significantly lower after surgery. The authors came to the conclusion that for the first time the benefits of a perioperative education program in a multicentric approach had been demonstrated. Pain assessments were better in particular groups of patients who underwent minor surgery and in patients without previous preoperative pain. It was shown that special attention should be paid to patients with preoperative pain.

In the last study analysed, the authors found positive results in the field of perioperative education - unlike the above-mentioned studies, in which the authors found serious shortcomings in the knowledge of the treatment of postoperative pain.

In most of the expert sources analysed, the authors agreed that patients were provided with inadequate treatment for postoperative pain and that barriers that prevent adequate treatment had to be removed. However, they do not mention concrete solutions to problems and do not make concrete proposals to remove barriers to provide patients with adequate treatment. In other sources (eg Borys et al., 2018; Eshete et al., 2019), the authors concluded that the treatment of postoperative pain is not in accordance with international standards and procedures, but they did not suggest a solution to the issue.

In post-operative pain management, it is not only the knowledge of medical and nursing staff and well-established standardised procedures in individual healthcare facilities that are important. Equally important in post-operative pain management are, among other things, the attitudes and motivations of staff, which play an important role in the acceptance of recommendations, their implementation and in long-term compliance.

\section{Conclusions}

Many foreign studies have dealt with the issue of postoperative pain management - but on a rather general level. The current state of postoperative pain treatment is usually viewed as inadequate.All the sources analysed report that postoperative pain is not adequately controlled and patients report that pain is evaluated, but not always using appropriate scales. In the literature review, from available studies and expert sources we verified that the process of care for patients with postopera- 
tive pain (ie postoperative pain management) is not sufficiently standardised, and there are no clear recommendations that are available in international guidelines (use of recommended scales and tools for evaluation pain, assessment interval). Deficiencies in the education of general nurses regarding the management of postoperative pain are mentioned as the most important problem. The second problematic point is the different level of competence and autonomy in analgotherapy. No study in the field of post-operative pain management from the Czech Republic was found from the available sources. Foreign studies point to a high workload that can affect the quality of care and the ability of nurses to manage pain in postoperative patients. There are standardised procedures focusing on the management of postoperative pain, but there is no coordinated use at both the local health service provider and the national level in the countries where the studies were conducted.

Based on the identified shortcomings, the decision was made to analyse the knowledge and experience of nurses in the management of post-operative pain in countries with a completely different social environment, specifically between respondents from the Czech Republic and the Kingdom of Saudi Arabia. In both countries, the competences and the culture and autonomy of nurses in the workplace differ. Our literary research was very beneficial as a theoretical basis for the subsequent analysis. Treatment of postoperative pain in patients should be more effective. One recommendation to improve pain management is the introduction of standardised procedures and the use of tools to measure pain in postoperative patients so that general nurses use a single tool and adequately assess postoperative pain in patients.

The literature review confirmed the importance and necessity of further investigation of treatment and evaluation of postoperative pain in patients. The results of the individual studies mentioned in the literature review can bring new knowledge in the treatment of postoperative pain and serve as a tool for improving the management of postoperative pain.

\section{Ethical aspects and conflict of interests}

The literature review was conducted in accordance with ethical rules. Our literary review and its methodology did not require any written consent of specific persons. The authors declare that they have no conflict of interest.

\section{Acknowledgements}

The paper was created with the support of the grant project: Management of pain in the postoperative period, knowledge and experience of general nurses (Czech Republic and Kingdom of Saudi Arabia) - SGS05 / 2019-2020, Faculty of Medicine, University of Ostrava.

\section{Management pooperační bolesti}

\section{Souhrn}

Cíl: Zhodnotit dostupné odborné poznatky v managementu pooperační bolesti. Literární rešerše je východiskem pro výzkum, který zkoumá znalosti a zkušenosti všeobecných sester v managementu pooperační bolesti (v České republice a v Království Saúdské Arábie).

Metodika: Literární rešerše - zvolená klíčová slova s využitím booleovských operátorů byla vyhledávána v elektronických databázích (MEDLINE, EBSCO, CINAHL, ACADEMIC SEARCH ULTIMATE, SCIENCE DIRECT).

Výsledky: Vyhledáno bylo celkem 469 zdrojů. Kritické analýze bylo podrobeno 25 zdrojů splňujících stanovená kritéria a k finální analýze bylo zvoleno celkem 7 studií, které byly zaměřeny na management pooperační bolesti u dospělé populace.

Závěr: V léčbě pooperační bolesti jsou dostupná mezinárodní doporučení, ale podle analyzovaných zdrojů nejsou doporučené postupy uplatňovány v klinické praxi. Výsledky literární rešerše prokázaly, že existují nedostatky zejména ve vědomostech všeobecných sester při zvládání pooperační bolesti a nejsou užívány standardizované postupy a nástroje pro hodnocení bolesti u pacientů v časném pooperačním období. Odborné zdroje doporučují klást větší důraz na vzdělávání všeobecných sester v managementu pooperační bolesti a jejího hodnocení v časném pooperačním období.

Klíčová slova: farmakologie; hospitalizovaný; management; pooperační bolest; všeobecná sestra

\section{References}

1. Angelini E, Wijk H, Brisby H, Baranto A (2018). Patients experiences of pain have an impact on their pain management attitudes and strategies. Pain Manag Nurs 19(5): 464-473. DOI: 10.1016/j.pmn.2018.02.067.

2. Azam MA, Weinrib AZ, Montbriand J, Burns LC, McMillan K, Clarke H, et al. (2017). Acceptance and Commitment therapy to manage pain and opioid use after major surgery: Preliminary outcomes from the Toronto General Hospital transitional pain service. Canadian Journal of Pain 1(1): 37-49. DOI: 10.1080/24740527.2017.1325317.

3. Borys M, Zyzak K, Hanych A, Domagała, M, Gałkin P, Gałaszkiewicz K, et al. (2018). Survey of postoperative pain control in different types of hospitals: a multicentre observational study. BMC Anaesthesia 18(1): 83. DOI: 10.1186/ s12871-018-0551-3.
4. Chapman JLR, Lalkhen AG (2016). Postoperative analgesia. Anaesthesia and Intensive Care Medicine 17(3): 144-150. DOI: 10.1016/j.mpaic.2016.01.001.

5. de Castro CC, da Silva Pereira AK, Bastos BR (2018). Implementation of the evaluation of pain as the fifth vital sign. J Nurs 12(11). DOI: 10.5205/1981-8963-v12i11a236994p3009-3014-2018.

6. Di Santo L (2019). Postoperative cognitive decline: the nurse's role in identifying this underestimated and misinterpreted condition. Br J Nurs 28(7). DOI: 10.12968/bjon.2019.28.7.414.

7. Drake G, de C Williams AC (2017). Nursing education interventions for managing acute pain in hospital settings: A systematic review of clinical outcomes and teaching methods. Pain Manag Nurs 18(1): 3-15. DOI: 10.1016/j. pmn.2016.11.001.

8. Erden S, Arslan S, Deniz S, Kaya P, Gezer D (2017). A review of postoperative pain assessment records of nurses. Appl Nurs Res 38: 1-4. DOI: 10.1016/j.apnr.2017.08.003. 
9. Eshete MT, Baeumier PI, Siebeck M, Tesfaye M, Haileamlak A, Michael GG, et al. (2019). Quality of postoperative pain management in Ethiopia: A prospective longitudinal study. PLoS One 14(5): e0215563. DOI: 10.1371/journal. pone.0215563.

10. Fang H, Liang J, Hong Z, Sugiyama K, Nozaki T, Kobayashi S, et al. (2017). Psychometric evaluation of the Chinese version of the revised American Pain Society patient outcome questionnaire concerning pain management in Chinese orthopedic patient. PLoS One 12(5): e0178268. DOI: 10.1371/ journal.pone.0178268.

11. Gabrhelík T, Pieran M (2012). Léčba pooperační bolesti. Interní Medicína 14(1): 23-25.

12. International Association for the Study of Pain (2017). IASP Terminology, Pain Terms. IASP-Pain.org. [online] [cit. 201912-19]. Available from: https://www.iasp-pain.org/Education/ Content.aspx? ItemNumber $=1698$ \#Pain

13. Jonan AB, Kaye AD, Urman RD (2018). Buprenorphine formulation: Clinical best practice strategies recommendations for perioperative management of patients undergoing surgical or interventional pain procedures. Pain Physician 21(1): E1E12.

14. Jungquist $C R$, Pasero $C h$, Tripoli NM, Gorodetsky R, Metersky M, Polomano RC (2014). Instituting best practice for monitoring for opioid-induced advancing sedation in hospitalized patients. Worldviews Evid Based Nurs 11(6): 350-360. DOI: 10.1111/wvn.12061.

15. Madsen SB, Qvist N, Möller S, Schultz H (2018). PatientControlled oral analgesia for acute abdominal pain: A beforeand-after intervention study on pain intensity and use of analgesics. Appl Nurs Res 40: 110-115. DOI: 10.1016/j. apnr.2018.01.007.

16. Málek J, Ševčík P, et al. (2017). Postoperative Pain Management. Praha: Mladá fronta DNES, 3rd updated revision. [online] [2019-12-19]. Available from: https://www.wfsahq.org/ components/com_virtual_library/media/125136f77e1b7daf75 65bd6653026c35-Postoperative-Pain-Management-170518.pdf

17. Masigati HG, Chilonga KS (2014). Postoperative pain management outcomes among adults treated at a tertiary hospital in Moshi, Tanzania. Tanzan J Health Res 16(1):47-53. DOI: 10.4314/thrb.v16i1.7.

18. Minkowitz HS, Gruschkus SK, Shah M, Raju A (2014). Adverse drug events among patients receiving postsurgical opioids in a large healthy system: Risk factors and outcomes. Am J Health Syst Pharm 71(18): 1556-1565. DOI: 10.2146/ajhp130031.
19. Ng L, Cashman J (2018). The management of acute pain. Medicine 46(12): 780-785. DOI: 10.1016/j. mpmed.2018.09.009.

20. Pogatzki-Zahn E, Kutschar P, Nestler N, Osterbrink J (2015). A prospective Multicentre Study to Improve Postoperative Pain Identification of Potentialities and Problems. PLoS One 10(11): e0143508. DOI: 10.1371/journal.pone.0143508.

21. Riswold K, Brech A, Petersen R, Schepper S, Wegehaupt A, Larsen-Engelkes T, et al. (2018). A biopsychosocial approach to pain management. S D Med 2018 Nov 71(11): 501-504.

22. Schreiber JA, Cantrell D, Moe KA, Hench J, McKinney E, Lewis CP, et al. (2014). Improving knowledge, assessment, and attitudes related to pain management: Evaluation of an intervention. Pain Manag Nurs 15(2): 474-481. DOI: 10.1016/j. pmn.2012.12.006.

23. Tyson E, Creagh-Brown B (2018). Postoperative care. Medicine 46(12): 750-753. DOI: 10.1016/j.mpmed.2018.09.003.

24. Veal FC, Thompson AJ, Perry LJ, Bereznicki LR, Peterson GM (2017). Pain intensity and pain self-management strategies following discharge after surgery: An Australian prospective observational study. J Clin Pharm Ther 43(1): 8-14. DOI: $10.1111 /$ jcpt.12584.

25. Woldehaimanot TE, Eshetie TCH, Kerie MW (2014). Postoperative pain management among surgically treated patients in an Ethiopian hospital. PLoS One 9(7): e102835. DOI: 10.1371/journal.pone.0102835

26. Xavier AT, DeLima MK, Burgos TMR, DeLira MCC, Serrano SQ (2018). Evaluation of postoperative pain under the nurse's point of view. J Nurs UFPE online 12(9): 2436-2441. DOI: 10.5205/1981-8963-v12i9a234730p2436-2441-2018.

27. Yaban ZS (2019). Usage of Non-Pharmacologic Methods on Postoperative Pain Management by Nurses: Sample of Turkey. Int J Caring Sci 12(1): 529-541. DOI: 10.4172/2375-4273-C6053

28. Yassin K, Rankin J, Al-Tawafsheh A (2015). The social organization of Nurse's pain management work in Qatar. Pain Manag Nurs 16(5): 759-769. DOI: 10.1016/j.pmn.2015.06.005.

29. Yüceer S (2011). Nursing approaches in the postoperative pain management. Journal of Clinical and Experimental Investigations 2(4): 474-478. DOI: 10.5799/ ahinjs.01.2011.04.0100.

30. Zoëga M, Sveinsdottir H, Sigurdsson GH, Aspelund T, Ward SE, Gunnarsdottir S (2014). Quality pain management in the hospital setting from the patient's perspective. Pain Prac 15(3): 236-246. DOI: 10.1111/papr.12166. 